\title{
The effects of viral load on pseudorabies virus gene expression
}

Judit S Tóth ${ }^{\dagger}$, Dóra Tombácz ${ }^{\dagger}$, Irma F Takács, Zsolt Boldogkői

\begin{abstract}
Background: Herpesvirus genes are classified into distinct kinetic groups on the basis of their expression dynamics during lytic growth of the virus in cultured cells at a high, typically 10 plaque-forming units/cell multiplicity of infection (MOI). It has been shown that both the host response and the success of a pathogen are dependent on the quantity of particles infecting an organism. This work is a continuation of an earlier study [1], in which we characterized the overall expression of PRV genes following low-MOI infection. In the present study, we have addressed the question of whether viral gene expressions are dependent on the multiplicity of infection by comparing gene expressions under low and high-MOI conditions.

Results: In the present study, using a real-time RT-PCR assay, we address the question of whether the expression properties of the pseudorabies virus (PRV) genes are dependent on the number of virion particles infecting a single cell in a culture. Our analysis revealed a significant dependence of the gene expression on the MOI in most of these genes. Specifically, we found that most of the examined viral genes were expressed at a lower level at a low $\mathrm{MOI}(0.1)$ than at a high $\mathrm{MOI}(10)$ experiment in the early stage of infection; however, this trend reversed by six hour post-infection in more than half of the genes. Furthermore, in the high-MOI infection, several PRV genes substantially declined within the 4 to 6-h infection period, which was not the case in the low-MOI infection. In the low-MOI infection, the level of antisense transcript (AST), transcribed from the antiparallel DNA strand of the immediate-early 180 (ie180) gene, was comparable to that of ie180 mRNA, while in the high-MOI experiment (despite the 10 times higher copy number of the viral genome in the infected cells) the amount of AST dropped by more than two log values at the early phase of infection. Furthermore, our analysis suggests that adjacent PRV genes are under a common regulation. This is the first report on the effect of the multiplicity of infection on genome-wide gene expression of large DNA viruses, including herpesviruses.

Conclusion: Our results show a strong dependence of the global expression of PRV genes on the MOI. Furthermore, our data indicate a strong interrelation between the expressions of ie180 mRNA and AST, which determines the expression properties of the herpesvirus genome and possibly the replication strategy (lytic or latent infection) of the virus in certain cell types.
\end{abstract}

\section{Background}

Pseudorabies virus (PRV), an alpha-herpesvirus, and the causative agent of Aujeszky's diseases of swine [2], is a commonly used model organism for studies in pathogenesis and the molecular biology of herpesviruses. Furthermore, it is widely utilized as a neural circuit tracer $[[3,4]$ and $[5]]$ and has been reported to be suitable as a vector for gene delivery to various cells $[6,7]$ and as

\footnotetext{
* Correspondence: boldog@sb4.szote.u-szeged.hu

† Contributed equally

Department of Medical Biology, Faculty of Medicine, University of Szeged Somogyi B. st. 4., Szeged, H-6720, Hungary
}

an oncolytic agent [8]. The gene expressions of herpesviruses are currently undergoing intensive investigation in consequence of the development of new technologies allowing simultaneous analysis of the expressions of multiple genes. DNA microarray approaches have been applied for the overall analysis of herpesvirus gene expression in several studies $[[9,10]$ and $[11]]$. Microchip techniques are powerful tools that permit simultaneous measurement of the relative changes in quantity of thousands of genes of an organism, and the comparison of gene expression profiles under various circumstances. Quantitative real-time RT-PCR is a much more sensitive 
and accurate method, but, at least at present, it is not well suited for the analysis of large numbers of samples. The herpesvirus genome however is, within the range that can be successfully analysed with this technique [1].

The program of herpesvirus gene expression is controlled at multiple levels by complex interactions between viral and cellular factors. The lytic gene expressions of herpesviruses are strictly coordinated in a sequential cascade manner and are traditionally subdivided into immediate-early (IE), early (E) and late (L) phases. IE proteins are involved in the control of the synthesis of E and L genes. The IE180 gene (ie180; homologue of the HSV ICP4 gene) is the only IE gene of PRV, and the most important regulator of viral gene expression. The E genes of herpesviruses are involved in various aspects of DNA synthesis, while most L genes mainly encode the structural elements of the virus. The antisense transcripts LLT (long latency transcript) and LAT (latency-associated transcript) overlapping the ICP4 and ICP0 (a homologue of epO in PRV), respectively, are reported to play important roles in the establishment of latency in HSV [12]. It has not yet been unequivocally clarified whether the expression of antisense transcript produced by the complementary DNA strand of the ie180 gene is controlled solely by the LAP (LAT promoter) producing LLT or also by a putative promoter (antisense promoter, ASP) localized on the inverted repeat of the PRV genome, producing a shorter transcript. In this study, we use the term 'antisense transcript' (AST) for the RNA molecule transcribed from the complementary DNA strand of the ie 180 gene.

It is well known that both the host response and the success of a pathogen are dependent on the quantity of particles infecting an organism; and, specifically in herpesviruses, the infecting dose determines whether the virus enters a latent state or induces an acute infection [13]. A further important question is whether the global gene expression profile of the virus genome is dependent on the number of virus particles entering the cells. In both traditional and microarray studies, herpesvirus gene expression has been analysed by using a relatively high multiplicity of infection, typically MOI 10 plaqueforming unit (pfu)/cell [9-11]. Theoretically, it is possible that herpesviruses express their genomes in a different manner when only a single virus particle infects a cell as compared with the situation when multiple virions enter a cell. In the present study, we addressed this issue by using low (0.1 pfu/cell) and high (10 pfu/cell) MOIs for the infection of cultured porcine kidney epithelial cells with wild-type PRV, and subsequently analysed and compared the expressions of 37 PRV genes and two antisense transcripts (AST and LAT) using the SYBR Green-based real-time RT-PCR technique.

\section{Results and Discussion}

\section{Experimental design}

In this study, PK-15 cells were infected with pseudorabies virus at MOIs of 0.1 and 10. Albeit the difference in the infectious dose in the two parallel experiments was 100 -fold, an individual cell was invaded by only 10 times more virus particles in the high-MOI than in the low-MOI experiment $\left(5 \times 10^{6}\right.$ versus $5 \times 10^{5}$ infected cells), the reason for this being that in the latter case approximately $90 \%$ of the cells remained uninfected. Cells were harvested at $0,1,2,4$ and $6 \mathrm{~h}$ postinfection (pi), as in our earlier report [1]. We used $6 \mathrm{~h}$ as the maximum infection period in order to exclude the possibility of the initiation of new infection cycles in the low-MOI experiment. In this study, we analysed the expression of 37 genes (53\% of the total PRV genes) and two antisense transcripts (AST and LAT) (Figure 1 and 2[14-45]). For the calculation of relative expression ratios (Rs) (Additional file 1a), we used the average $6 \mathrm{~h}$ $E^{C t}$ values of the high-MOI experiments of both the "samples" and the "references" as controls, as in our earlier publication [1]. We used a correction factor of 10 for the calculation of R for the low-MOI experiment (Additional file 2a). With this calculation technique, approximately the same numbers of infected cells, and hence the relative amounts of transcripts in an average infected cell, were compared in the two experiments. However, in the high-MOI experiment, the proportion of the genome copy number in an infected cell was also 10-fold higher on average, at least before the start of viral DNA replication (the first $2 \mathrm{~h}$ pi), the reason for this being that in the high-MOI experiment 10 virus particles infected an average cell, while in the low-MOI infection 10 per cent of the cells were infected with a single virus particle. Thus, to compare the gene expressions from a single virus DNA per cell, two normalizations are necessary: multiplication of the $R$ values of the low-MOI data by 10 , and division of the $R$ values of the high-MOI data by 10 . In some calculations, the original data were handled accordingly (see the indications in the particular cases). The relationship between the infectious dose and the genome copy number of PRV becomes non-linear in later stages of viral infection; the DNA copy numbers in the two experimental situations are therefore not comparable on the basis of the infectious dose. The R values of LAT and AST were calculated by using the $6 \mathrm{~h} \mathrm{E}^{\mathrm{Ct}}$ values of the corresponding genes, ep0 and ie180, respectively, as the reference gene. $\mathrm{R}_{\Delta}$ values were used to monitor the net change in the quantity of viral transcripts within a given period of time (Additional file $2 b$ ). $R_{a}$ shows the ratio of the changes in the amounts of transcripts between two adjacent time points (Additional file 2c). 

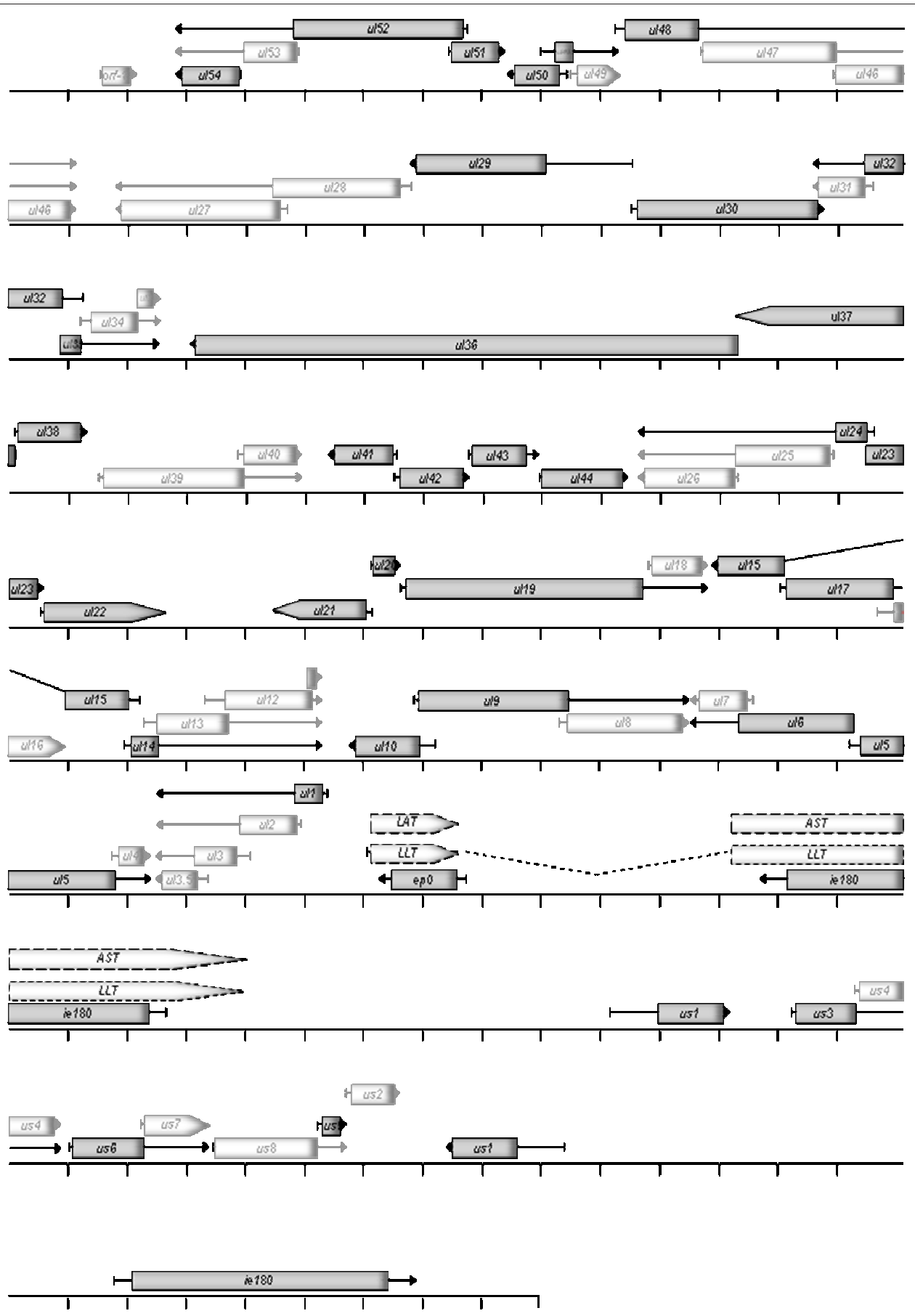

Figure 1 Localization of PRV genes on the viral genome. This Figure shows the genomic locations of the PRV genes. The direction of transcription is indicated by the arrows. Grey boxes indicate examined genes. Broken-line boxes show the known antisense transcripts of PRV. Unexamined genes are shown as white boxes.

We considered two principles for the selection of genes for expression analyses. (1) We analysed the upstream genes of each nested gene cluster, the reason for this being that these genes are not overlapped by other genes, and the amounts of these transcripts are therefore proportional to their protein products. This is in contrast with the downstream genes, which, if transcribed from the promoter of an upstream gene, are not translated, because they do not have cap sequences that are required for the recognition by the ribosomes. 


\begin{tabular}{|c|c|c|c|}
\hline Gene name (II) & Kinetic class $^{\S}$ & Function & References \\
\hline ul54 (IICP27) & E & Ittranscription regulator & [14] \\
\hline$u l 52$ & $\mathrm{E}$ & Thelicase-primase complex & [15] \\
\hline$u l 51$ & $\mathrm{~L}$ & protein-protein interaction tegument & [16] \\
\hline ul50 (IddUTPase) & $\mathrm{E}$ & dUTPase, virulence faktor & [17] \\
\hline$u l 49.5(\mathrm{gN})$ & $\mathrm{L}$ & virion entry, egress & [18] \\
\hline ul48 (IIVP16, $\alpha$-TIF) & $\mathrm{L}$ & virion formation, gene regulator & [19] \\
\hline ul29 (IIICP8) & $\mathrm{E}$ & DNA replication, DNA binding & [20] \\
\hline ul30 & E & IDNA polymerase, replication & [21] \\
\hline$u l 32$ & $\mathrm{~L}$ & DNA cleavage and encapsidation & [22] \\
\hline$u l 33$ & $\mathrm{~L}$ & DNA cleavage and packaging & [22] \\
\hline ul36 (IIVP1/2) & $\mathrm{L}$ & virion morphogenesis & [23] \\
\hline$u l 37$ & $\mathrm{~L}$ & viral egress & [23] \\
\hline ul38 (IIVP19c) & $\mathrm{L}$ & virion production & [24] \\
\hline ul41 (VHS) & $\mathrm{L}$ & RNase activity & [25] \\
\hline$u l 42$ & $\mathrm{~L}$ & DNA replication & [26] \\
\hline$u l 43$ & $\mathrm{E} / \mathrm{L}$ & modulating fusion processes & [27] \\
\hline ul44 $(\mathrm{gC})$ & $\mathrm{L}$ & viral entry, virion attachment & [28] \\
\hline ul24 (IIVP24) & $\mathrm{L}$ & unknown & [29] \\
\hline$u l 23(\mathrm{TK})$ & $\mathrm{E}$ & nucleotide synthesis & [26] \\
\hline$u l 22(\mathrm{gH})$ & $\mathrm{L}$ & viral entry, cell-cell spread & [30] \\
\hline$u l 21$ & $\mathrm{E}$ & capsid maturation & [31] \\
\hline$u l 20$ & $\mathrm{E} / \mathrm{L}$ & viral egress & [32] \\
\hline ul19 (IIVP5) & $\mathrm{L}$ & virion production, capsid protein & [33] \\
\hline ul17 & $\mathrm{L}$ & DNA cleavage and packaging & [34] \\
\hline ul15 & $\mathrm{E} / \mathrm{L}$ & DNA cleavage and encapsidation & [35] \\
\hline ul14 & $\mathrm{E} / \mathrm{L}$ & Iunknown & [36] \\
\hline ul10 (gM) & $\mathrm{L}$ & membrane fusion & [36] \\
\hline$u l 9$ (I[OBP) & $\mathrm{E}$ & DNA synthesis & [37] \\
\hline ul6 & $\mathrm{L}$ & Capsid protein, portal protein & [38] \\
\hline$u l 5$ & $\mathrm{~L}$ & DNA replication & [39] \\
\hline ull $(\mathrm{gL})$ & $\mathrm{L}$ & viral entry, cell-to-cell spread & [38] \\
\hline$L A T$ & $\mathrm{~L}$ & Ilatency & [39] \\
\hline$A S T$ & $\mathrm{E}$ & Ilatency & [39] \\
\hline ep0 (IICP0) & $\mathrm{E}$ & gene regulation & [40] \\
\hline ie180 (IIICP4) & $\mathrm{E} / \mathrm{L}$ & gene regulation & [41] \\
\hline us1 (IIRSp40/ICP22) & $\mathrm{L}$ & Iregulator of gene expression & [42] \\
\hline us 3 (PK) & $\mathrm{E}$ & egress, cell-to-cell spread & [43] \\
\hline us6 (gD) & $\mathrm{E} / \mathrm{L}$ & viral entry & [44] \\
\hline us9 (đI11K) & $\mathrm{E} / \mathrm{L}$ & anterograde spreed of virus & [45] \\
\hline
\end{tabular}

If- HSV homologue/function

${ }^{\S}$-[11]

Figure 2 List of PRV genes analysed in this study. This Figure presents the kinetic classification of the examined PRV genes, and their functional assignment.

(2) Furthermore, we analysed genes that are of primary importance in the regulation of global viral gene expression, such as ie180, ep0,vhs and ul54.

\section{Gene expressions in the early stage of PRV infection}

In the first $2 \mathrm{~h}$ of infection, the viral DNA replication has not yet been initiated, and the copy number of viral genomes in a cell therefore corresponds with the infectious dose. In this analysis, we found that the mRNA levels of most examined PRV genes were higher in the cells infected with the high MOI than in those infected with the low MOI (Additional file 2a) at both $1 \mathrm{~h}$ and $2 \mathrm{~h}$ pi. This was not unexpected since in the former case viral DNAs were represented in an approximately 10 -fold higher proportion in an average infected cell. Exceptions to this were the transcripts $u l 1, u l 33$, and ul51 mRNAs at $1 \mathrm{~h}$ pi, and ul36, ul38, ul43, and ul48 mRNAs at $2 \mathrm{~h} \mathrm{pi}$, and at both $1 \mathrm{~h}$ and $2 \mathrm{~h}$ : ie180 and ul30 mRNAs, as well as, LAT and AST. However, the expression levels normalized to the genome copy 
number (i.e. using $\mathrm{R} / 10$ values in the high-MOI infection) showed an inverse pattern: only a few genes were expressed at higher abundance in the high-MOI than in low-MOI infection (Additional file 2a). AST was expressed at a considerably higher quantity in the cells infected with the low MOI than in those infected with the high MOI $\left(R_{\text {low MOI }} / R_{\text {high MOI }}=111\right.$-fold at $1 \mathrm{~h}$, and 298 -fold at $2 \mathrm{~h} \mathrm{pi)}$. The expression rate of a single genomic region encoding the AST was even 10 times higher (1 h: 1110 -fold and $2 \mathrm{~h}: 2980$-fold) in the low-dose infection experiment (Additional file 2a). In the highdose infection 6 of the 37 genes (ie180, ul36, ul50, ul54, us1, and ul24) exhibited higher expression levels at $1 \mathrm{~h}$ than at $2 \mathrm{~h}$ pi. It should be noted that 3 of them (ie180, us1 and ul54) are regulatory genes. The fourth regulatory PRV gene, epO, is expressed at a very high level during the first $2 \mathrm{~h}$ in the high-MOI infection $\left(\mathrm{R}_{1 \mathrm{~h}}=\right.$ $\left.1.87, \mathrm{R}_{2 \mathrm{~h}}=2.05\right)$. Apart from ep0, ul5 $\left(\mathrm{R}_{2 \mathrm{~h}}=1.2\right)$ was the only gene that was expressed at a higher extent in the early stages of infection than at $6 \mathrm{~h}$ pi in the highMOI experiment. The ie180 gene is the only one that was expressed in a higher amount at $1 \mathrm{~h}$ than at $2 \mathrm{~h}$ pi under both experimental conditions (Additional file 2). Overall, it appears that the 4 regulatory genes were expressed at relatively high levels before the onset of DNA replication in the high-MOI infection, which was not the case in low-MOI infection, with the exception of the ie180 gene. We think that the reason for the higher expression of regulatory genes at the onset of viral DNA replication in the high-MOI infection is that more regulatory proteins are needed to carry out the multiplication of a higher copy number of the viral genome. The rate of change in gene expression within the 1 $h$ to $2 \mathrm{~h}$ interval $\left(\mathrm{R}_{2 \mathrm{~h}} / \mathrm{R}_{1 \mathrm{~h}}\right)$ was higher in more than two-thirds of the PRV genes (25/37) in the low-MOI than in the high-MOI infection (Additional file 2c). The proportion of AST to ie180 mRNA molecules $\left(\mathrm{R}_{\mathrm{AST}} /\right.$ $\mathrm{R}_{\mathrm{ie} 180}$ ) was 0.47 at $1 \mathrm{~h} \mathrm{pi}$, and 4.72 at $2 \mathrm{~h}$ pi in cells infected with the low MOI, while this ratio was extremely low $(\sim 0.01)$ at both $1 \mathrm{~h}$ and $2 \mathrm{~h}$ pi in the highMOI infection (these data are only semi-quantitative since the primer efficiencies in the RT reaction are not necessarily equal for the two transcripts). Thus, the proportion of AST to ie $180 \mathrm{mRNA}\left[\left(\mathrm{R}_{\mathrm{AST}-\text { low MOI }} / \mathrm{R}_{\text {ie-low }}\right.\right.$ MOI $\left./\left(R_{\text {AST-high MOI }} / R_{\text {ie-high MOI }}\right)\right]$ was 39 -fold higher at $1 \mathrm{~h}$ pi and 293 -fold higher at $2 \mathrm{~h}$ pi in the low-MOI than in the high-MOI infection. In the early stages of PRV infection, the amount of AST was very high; it even significantly exceeded the level of ie 180 mRNAs at $2 \mathrm{~h}$ pi in the low-MOI infection, while the amount of AST and also its ratio to ie180 mRNA were extremely low in the high-MOI infection. Moreover, ie180 mRNA is expressed to a significantly higher extent in the lowMOI experiment despite the 10 times lower copy number of PRV DNA in an infected cell, which is especially important because IE180 is a DNA-binding protein. We think that this observation reveals an important regulatory mechanism of the herpesviruses, which is as follows: in a high-titre infection, the virus initiates a lytic infection in a cell, while in a low-titre infection, the virus has the choice of whether to establish a dormant state or enter a lytic cycle in a cell. The molecular mechanism of this phenomenon might be based on the interaction of ie180 and AST genes at both the transcription and translation levels. (1) The ie180 protein might exert a negative effect on the synthesis of AST, such as in LAT in HSV [46] by binding the promoter of the antisense transcript. (2) Furthermore, the complementary transcripts might mutually influence each other's expression transcript by RNA-RNA interaction. In a low-MOI infection, the two transcripts exhibit a complementary expression pattern, which indicates a competition between the two transcripts. In a high-MOI infection, however, the high initial amount of ie180 gene product inhibits the expression of AST. The significance of this infection strategy could be that, in the case of a low-amount infection, the virus has no chance to invade the host cells; therefore, it is better to hide against the immune surveillance.

The ep 0 gene is expressed in higher quantity at both 1 $\mathrm{h}$ pi $(4.22$-fold) and $2 \mathrm{~h}$ pi $(2.43$-fold) in the high-MOI infection than in low-MOI infection, which is in contrast with LAT, its antisense partner, whose expression level was lower in the high-MOI infection (1 h: 0,5-fold; $2 \mathrm{~h}$ : 0,18 -fold). Thus, the ratios of LAT to ep0 mRNA molecules were 8.33 -fold higher at $1 \mathrm{~h}$ pi and 13.05-fold higher at $2 \mathrm{~h}$ pi in the low-MOI than in the high-MOI experiment, although, unlike AST, LAT is abundantly expressed in the high-MOI infection. Accordingly, similarly to AST, LAT is expressed in a significantly higher proportion to epO mRNA in the low-MOI infection in the early stages of infection, which may also be important as concerns of the replication strategy of the virus. Our analyses additionally showed that AST and LAT are, at least partly, expressed independently from each other, which supports the existence of separate elements controlling the expressions of the two antisense transcripts. Indeed, AST was suggested to be controlled by an antisense promoter (ASP) localized in the outer regions of inverted repeats [47].

\section{Gene expressions in later stages of PRV infection}

At $4 \mathrm{~h}$ pi the transcript levels of more than three-quarters of the PRV genes (28/37) were still higher in the cells infected with the high MOI than in those infected with the low MOI (Additional file 2c). However, in about twothird of the viral genes the rate of change ( $R_{a}$ values) in the expression level was higher in the low-MOI than in 
the high-MOI infection (24/37 within the $2 \mathrm{~h}$ to $4 \mathrm{~h}$ period, and 25/37 within the $1 \mathrm{~h}$ to $4 \mathrm{~h}$ period) (Additional file 2c). In the low-MOI infection, the amounts of 5 transcripts (ul5, ul44, us 1 and us6) were less than $10 \%$ of those in the high-MOI infection at $4 \mathrm{~h}$ pi. All of the examined us genes are expressed at a significantly lower level in the low-than in the high-titre infection at $4 \mathrm{~h}$ pi. There were significant decreases in the quantities of both AST and LAT in the low-titre infection at $4 \mathrm{~h}$ pi relative to the $2 \mathrm{~h}$ values (AST: a 59-fold decrease, and LAT: a 7 -fold decrease). We explain this phenomenon by the negative effect of the regulatory genes on their antisense partners. Regulatory genes are upregulated at the onset of DNA replication (in order to facilitate this process), which exerts an inhibitory effect on the expression of AST and LAT. In contrast, there were increases in the amounts of antisense transcripts in the high-MOI (AST: an 11-fold increase, and LAT: a 7-fold increase) in this time interval. However, while LAT was expressed at high level $(\mathrm{R}=1.3)$ under the high-MOI conditions, the AST expression remained extremely low $(R=0.013)$ in this period of infection. The amount of the ie180 transcript was practically unchanged within the $2 \mathrm{~h}$ to $4 \mathrm{~h}$ infection period under either infection conditions. There was a 4.7 -fold increase in the ep 0 mRNA level within the $2 \mathrm{~h}$ to $4 \mathrm{~h}$ infection period $\left(\mathrm{R}_{4 \mathrm{~h}} / \mathrm{R}_{2 \mathrm{~h}}\right)$ in the low-MOI infection, as compared with only 1.4 in the high-MOI experiment. On average, the amounts of mRNAs in low titre infection became higher than those in the high-infection titre by $6 \mathrm{~h}$ pi in more than half of the PRV genes (22/37). We assume that the reason for this might be that the ie180 gene, the major coordinator of gene expression, is expressed at higher levels at 4 and $6 \mathrm{~h}$ pi at low-MOI than at high-MOI infection. Moreover, in the high-MOI infection the amount of AST reached almost $30 \%$ of the transcript level in the low-MOI infection, while LAT was expressed at approximately the same level under the two infection conditions at $6 \mathrm{~h}$ pi. The genes expressed at lower levels in the low-dose infection appeared to be clustered on adjacent genomic locations (Figure 1). Each gene and the two antisense transcripts were expressed at higher rates ( $R_{a}$ values) within the $4 \mathrm{~h}$ to $6 \mathrm{~h}$ period in the low-MOI than in the high-MOI infection without exception (Additional file 1c). In the high-MOI infection, 11 genes and LAT peaked at $4 \mathrm{~h}$ within the 6-h examination period, while in the low-MOI infection only the us3 transcript had a slightly lower $R$ value at $6 \mathrm{~h}$ than at $4 \mathrm{~h}$ pi. The us3 gene was the only one among the 70 PRV genes which was expressed at a higher level at $4 \mathrm{~h}$ than at $6 \mathrm{~h}$ pi in another study [1]. Intriguingly, the ep0 mRNAs reached a 3.5-fold higher level in the low-dose than in the high-dose infection in an average cell at $6 \mathrm{~h}$ pi. Furthermore, at $6 \mathrm{~h}$ pi the $u l 1$ and $u l 51$ genes were expressed at an approximately 10 times higher level under the low-MOI than under the high-MOI conditions.

\section{Gene expression kinetics within the 0 to 6 -h infection period}

The expression of most PRV genes basically differed under the two infection conditions (Additional file 1c), which is in contrast with the case of rhesus monkey rhadinovirus (a $\gamma$-herpesvirus), whose lytic gene expression commences at a fixed pace in infected cells, regardless of the MOI [48]. Most genes were expressed at a lower level in a cell in the low-MOI experiment in the first $4 \mathrm{~h}$ of infection, but more than half of these gene products surpassed the high-MOI values by $6 \mathrm{~h}$ pi. The $R$ values of 3 PRV genes (ie180, ul1 and ul30) were higher in the low-MOI than in the high-MOI infection at every examined time point, while the opposite was true (the $\mathrm{R}$ values of high-MOI were always higher) in 13 genes: ul5, ul15, ul17, ul19, ul23, ul24, ul44, ul49.5, ul54, us6, us9, us1 and us3 (Figure 3). These latter genes form clusters on the basis of their localization on the genome (genes in close vicinity are underlined), which suggests that the adjacent genomic sequences might be under common regulatory control. This observation is supported by the similarity of the $R_{a}$ curves of adjacent genes (Additional file 1c). For example, the expression rates of the $u l 36, u l 37$ and $u l 38$ genes were similar to each other in both experiments, but each of them exhibited an inverse expression pattern in the two infection conditions. All genes were expressed at a higher rate $\left(\mathrm{R}_{\mathrm{a}}\right)$ within the $1 \mathrm{~h}$ to $6 \mathrm{~h}$ period of infection in the lowtitre experiment, except for ie180 and the two antisense transcripts. The quantities of ie180 mRNAs were similar in the two experiments, except at $1 \mathrm{~h} \mathrm{pi}$, where the level of the transcripts was 2.8-fold higher in the low-MOI infection. Thus, the amount of total ie180 transcript in an infected cell appears to be under strict control, independently of the initial infection conditions. In contrast, the expression of the ep 0 gene differed basically in the two experiments. In the high-MOI experiment, the amount of ep0 mRNAs was high from the first hour of infection, and its expression even declined by $6 \mathrm{~h}$ in the high-MOI infection, while the amount of these transcripts rapidly increased throughout the 6-h infection period in the low-dose infection, and reached a 3.5-fold higher level compared to that of the high-dose infection by $6 \mathrm{~h}$. (Figure 4 ) The ratio of sense and antisense transcripts during the 6-h infection period displayed intriguing patterns. First of all, in the high-MOI infection the amount of AST and its ratio to ie180 mRNA were very low throughout the 6 -h infection period. We demonstrated an inverse relationship in the expression kinetics of ie180 mRNA and AST and also ep0 mRNA and LAT in the low-MOI infection; however, we did not 


\begin{tabular}{|c|c|c|c|c|c|}
\hline Gene (Kinetic class) & $1 \mathrm{~h} / 1 \mathrm{~h}$ & $2 \mathrm{~h} / 2 \mathrm{~h}$ & $4 \mathrm{~h} / 4 \mathrm{~h}$ & $6 \mathrm{~h} / 6 \mathrm{~h}$ & \\
\hline ul54 (Early) & 0.135 & 0.396 & 0.436 & 0.676 & \\
\hline ul52 (Early) & 0.088 & 0.322 & 1.777 & 3.785 & \\
\hline ul50 (Early) & 0.164 & 0.947 & 0.951 & 1.638 & \\
\hline ul29 (Early) & 0.428 & 0.452 & 0.749 & 1.006 & \\
\hline ul30 (Early) & 1.671 & 1.746 & 1.253 & 3.185 & \\
\hline ul23 (Early) & 0.152 & 0.122 & 0.211 & 0.398 & \\
\hline ul21 (Early) & 0.801 & 0.834 & 1.001 & 1.252 & \\
\hline ul9 (Early) & 0.296 & 0.686 & 0.679 & 1.089 & \\
\hline ep0 (Early) & 0.237 & 0.411 & 1.363 & 3.490 & \\
\hline us3 (Early) & 0.093 & 0.117 & 0.210 & 0.231 & \\
\hline AST (Early) & 110.821 & 297.500 & 0.448 & 3.389 & \\
\hline ul43 (Early late) & 0.654 & 1.921 & 1.087 & 1.532 & \\
\hline ul20 (Early late) & 0.236 & 0.210 & 0.717 & 2.112 & \\
\hline ul15 (Early late) & 0.052 & 0.139 & 0.358 & 0.739 & \\
\hline ul14 (Early late) & 0.501 & 0.809 & 0.919 & 1.803 & 0.01 \\
\hline ie180 (Early late) & 2.816 & 1.014 & 1.119 & 1.325 & 0.02 \\
\hline us6 (Early late) & 0.130 & 0.158 & 0.090 & 0.199 & \\
\hline us9 (Early late) & 0.218 & 0.345 & 0.246 & 0.768 & 0 \\
\hline ul51 (Late) & 1.958 & 0.061 & 2.004 & 10.134 & 0.070 \\
\hline ul49,5 (Late) & 0.024 & 0.290 & 0.344 & 0.730 & 0.090 \\
\hline ul48 (Late) & 0.477 & 1.569 & 0.431 & 0.986 & $\begin{array}{l}0.100 \\
0.110\end{array}$ \\
\hline ul32 (Late) & 0.260 & 0.677 & 0.587 & 2.239 & $\begin{array}{l}0.110 \\
0.120\end{array}$ \\
\hline ul33 (Late) & 1.275 & 0.842 & 1.271 & 1.729 & 0.130 \\
\hline ul36 (Late) & 0.588 & 2.406 & 0.431 & 0.900 & 0.150 \\
\hline ul37 (Late) & 0.171 & 0.621 & 0.341 & 1.541 & $\begin{array}{l}0.160 \\
0.200\end{array}$ \\
\hline ul38 (Late) & 0.757 & 2.003 & 0.164 & 1.799 & 0.300 \\
\hline ul41 (Late) & 0.052 & 0.341 & 0.623 & 1.248 & 0.400 \\
\hline ul42 (Late) & 0.291 & 0.448 & 0.550 & 1.288 & 1.000 \\
\hline ul44 (Late) & 0.127 & 0.023 & 0.075 & 0.222 & $\begin{array}{l}2.000 \\
3.000\end{array}$ \\
\hline ul24 (Late) & 0.202 & 0.253 & 0.101 & 0.724 & 4.000 \\
\hline ul22 (Late) & 0.419 & 0.354 & 0.689 & 1.077 & 5.000 \\
\hline ul19 (Late) & 0.067 & 0.270 & 0.229 & 0.570 & $\begin{array}{l}6.000 \\
7.000\end{array}$ \\
\hline ul17 (Late) & 0.080 & 0.024 & 0.173 & 0.938 & 8.000 \\
\hline ul10 (Late) & 0.411 & 0.118 & 0.220 & 1.058 & 9.000 \\
\hline ul6 (Late) & 0.074 & 0.055 & 0.412 & 1.249 & 10.200 \\
\hline ul5 (Late) & 0.017 & 0.013 & 0.031 & 0.421 & \\
\hline ul1 (Late) & 2.017 & 1.179 & 1.532 & 8.854 & $>10.200$ \\
\hline us1(Late) & 0.168 & 0.679 & 0.077 & 0.563 & \\
\hline LAT (Late) & 1.973 & 5.371 & 0.078 & 1.122 & \\
\hline
\end{tabular}

Figure 3 Heatmap-like representation of the ratio of transcripts produced in the low-MOI and high $\mathrm{MOI}$ infection

$\left(\mathbf{R}_{\mathbf{t}}\right.$ low $\mathbf{M o l} / \mathbf{R}_{\mathbf{t}}$ high $\left.\mathbf{\text { Mol}}\right)$. PK-15 cells were infected with the PRV-Ka strain at different MOIs (0.1 and 10). Real-Time PCR data were normalised to $28 \mathrm{~S}$ RNAs. The $\mathrm{R}_{\text {low }} / \mathrm{R}_{\text {high }}$ values are plotted in a heat map-like manner. Black boxes indicate the highest ratio, and darkred boxes the lowest values. White boxes demonstrate approximately equal values.

observe this inverse relationship between the complementary transcripts under the high-MOI conditions (Figure 5). In an earlier report [1], we showed that treatment of infected cells with cycloheximide (a protein synthesis blocker) resulted in significant increases in the amounts of both ie180 mRNA and AST, while phosphonoacetic acid (a DNA synthesis inhibitor) treatment led to a decrease in ie180 mRNA and a significant increase in the AST level. These results suggest a negative effect of the IE180 transactivator on ASP synthesis. We explain the huge drop in ASP level in the infected cells in the early stage of the high-MOI infection by the
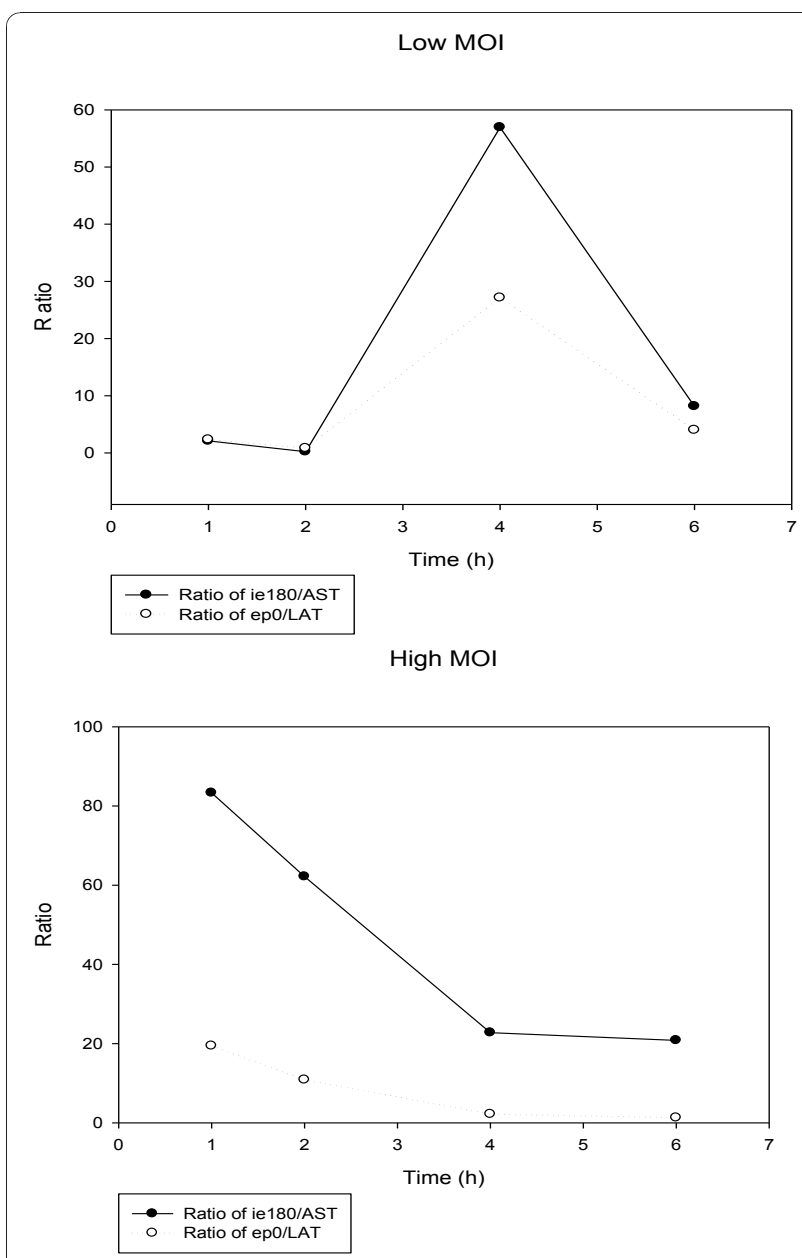

Figure 4 The ratio of ie180 and epo mRNAs to their antisense partners. The continuous lines illustrate the ratio of ie180 mRNA to AST, while the dotted lines represent the ratio of ep0 mRNA to LAT at the low- and high-MOI infections.

presence of a 10-fold higher amount of inhibitory IE180 protein localized in the tegument of the infecting virions [49]. The same reason could account for the lower ie180 mRNA level in the high-MOI infection. The us1 gene was expressed in the late kinetics in our earlier lowMOI analysis in both phophonoacetic acid-treated and non-treated samples. These results are in concordance with those of the present high-dose infection experiment, i.e. us 1 mRNA was expressed at a relatively low level at $1 \mathrm{~h}$, which even dropped by $2 \mathrm{~h}$ pi. The highest rate of us1 mRNA expression was observed at $4 \mathrm{~h}$, with a rate $\left(R_{4 h / 2 h}=13.32\right)$ typical of $L$ genes. The Pearson correlation coefficients of the $R, R_{\Delta}$, and $R_{a}$ values precisely show the degree of similarity (or differences) of the expression kinetics of the genes in the low- and high-MOI experiments (Additional file 3). Several genes exhibited high correlations for all three parameters. For example, the ie180, ul19, ul21, ul22, ul42 and ul43 

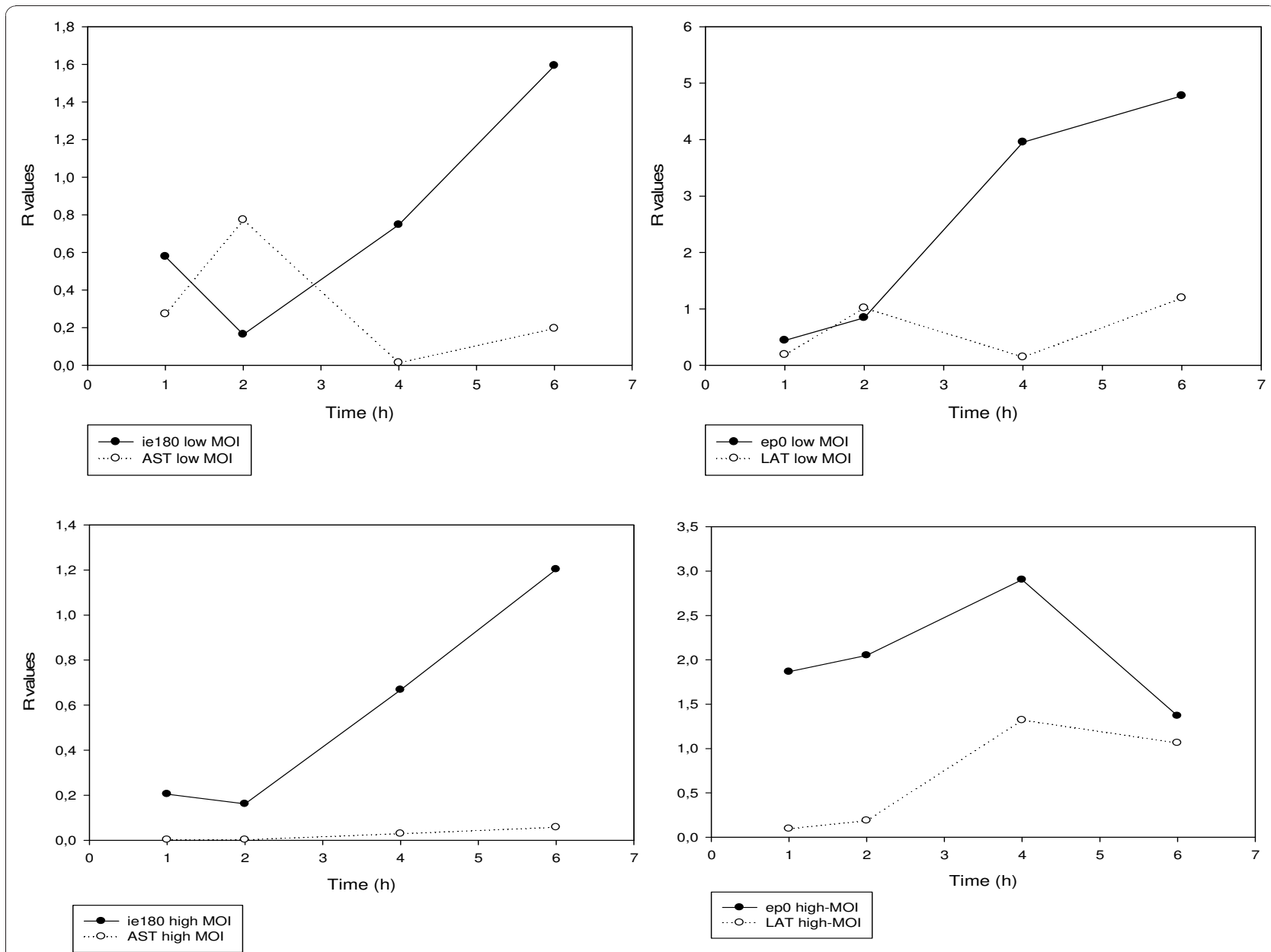

Figure 5 The R values of $i e 180$ and epo mRNAs and their antisense partners. These diagrams depict the expression curves of sense and antisense transcripts of two regulatory genes (ie/80 and ep0) at the different infectious doses. The continuous lines represent the level of sense transcripts at the given time points, while broken lines show the amounts of their antisense counterparts.

genes gave high correlation coefficients for the $\mathrm{R}, \mathrm{R}_{\Delta}$ and $R_{a}$ values. The us1 gene behaved in an irregular manner; it gave a relatively high correlation for the $\mathrm{R}$ values, no correlation of $\mathrm{R}_{\Delta}$, and an inverse correlation for the $R_{a}$ values. AST yielded relatively high negative values for all three parameters, indicating a significant negative correlation. The expressions of LAT under the two experimental conditions did not correlate on the basis of the $\mathrm{R}$ values, whereas it gave a very high negative correlation for its $R_{\Delta}$ and $R_{a}$ values. The effect of the MOI on the overall gene expression of HSV-1 has been investigated by Wagner and colleagues [50], who found that, following the infection of cultured cells by wild-type virus at MOIs ranging from 0.05 to $5 \mathrm{pfu} / \mathrm{cell}$, the temporal profiles of transcript abundance were essentially the same. This is in sharp contrast with our results. We explain the differences by the low resolution of the microarray technique that Wagner et al. used for their analysis. An analysis of the global transcription of Rhesus monkey rhadinovirus, a $\gamma$-herpesvirus, has revealed differential gene expression at different MOIs [48], but these data cannot be compared because they related to later time points $(12,24,4872$ and $96 \mathrm{~h})$ than in our analysis.

\section{Conclusion}

Our analysis has revealed that almost all of the examined PRV genes exhibited different expression dynamics under the two experimental conditions. Most PRV genes were expressed at a lower level in the low-MOI than in the high-MOI experiment in the early stages of infection; however, the reverse was true when the transcript levels were normalized to the genome copy numbers. In the low-MOI infection, slightly more than half of the PRV transcripts outran the high-MOI values by 6 h pi. The lower ie180 transcript per genome in the 
high-titre infection experiment might account for the lower level of global PRV gene expression per genome in the high-MOI infection. However, the expression of viral genes per DNA did not uniformly decrease; some genes even became more active in the high-MOI infection, which indicates the selective effect of the reduced availability of the IE180 protein. The most dramatic difference between the two MOI infections was observed in AST, which was expressed at a more than two log higher level in an infected cell in the low-MOI infection, which is a $3 \log$ higher activity of a single DNA region encoding the ASP. The ratio of LAT/EP0 was also significantly lower in the high-than in the low-MOI infection. The reasons for and the mechanisms of these phenomena remain to be clarified. Furthermore, genes localized in adjacent regions on the viral genome exhibited similar expression properties, indicating the existence of synchronizing mechanisms of gene expression.

\section{Methods}

\section{Virus, cells and infection}

Strain Kaplan (Ka) of pseudorabies virus (PRV) was used in our analyses. Immortalized porcine kidney (PK)-15 epithelial cells were applied for propagation of the virus. PK-15 cells were cultivated in Dulbecco's modified Eagle medium supplemented with $5 \%$ foetal bovine serum (Gibco Invitrogen) and $80 \mu \mathrm{g}$ gentamycin per $\mathrm{ml}$ at $37^{\circ} \mathrm{C}$ in the presence of $\mathrm{CO}_{2}$. The virus stock used for the experiments was prepared as follows. Rapidlygrowing semi-confluent PK-15 epithelial cells were infected at an MOI of $0.1 \mathrm{pfu} / \mathrm{cell}$ and were incubated until a complete cytopathic effect was observed. The cell debris was removed by low-speed centrifugation $(10,000$ $\mathrm{g}$ for $20 \mathrm{~min}$ ). The supernatant was concentrated and further purified by ultracentrifugation through a $30 \%$ sugar cushion at $24,000 \mathrm{rpm}$ for $1 \mathrm{~h}$, using a Sorvall AH-628 rotor. The number of cells in a culture flask (Corning, $150 \mathrm{~cm}^{2}$ ) was $5 \times 10^{6}$. In high-MOI and in low-MOI experiments, $5 \times 10^{7}$ and $5 \times 10^{5}$ pfu viral particles, respectively, were applied for the infections. Thus, in the high-MOI experiment, practically all the cells were infected, while in the low-MOI experiment, approximately $5 \times 10^{5}$ cells $(10 \%$ of the cells in a culture flask) were infected by the virus. We used the same data for the low-MOI experiment as in a previous publication [1]. The two experiments were run simultaneously. We ran four independent sets of measurements for each time point in both low and high-MOI studies, but occasionally we had to remove data because of low amplification efficiencies or the amplification of non-specific products in the reaction." Thus, in some genes, instead of four, we only used three independent data. Infected cells were incubated for $1 \mathrm{~h}$, followed by removal of the virus suspension and washing with phosphate-buffered saline. After the addition of new medium to the cells, they were incubated for $0,1,2,4$ or $6 \mathrm{~h}$. In this study, mock-infected cells were used as controls, which were otherwise treated in the same way as the infected cells.

\section{Isolation of RNAs}

RNA was extracted by using the NucleoSpin RNA II Kit (Macherey-Nagel GmbH and Co. KG), as described previously [1]. Briefly, after the cells had been collected by centrifugation and lysed by buffer containing chaotropic ions, the nucleic acids were docked to a silica column. The DNA was removed with RNase-free DNase solution (supplied with the NucleoSpin RNA II Kit). Finally, the RNAs were eluted from the column in RNase-free water (supplied with the kit). To eliminate the residual DNA contamination, all RNA samples were treated by an additional digestion with Turbo DNase (Ambion Inc.). The concentrations of the RNA samples were measured by spectrophotometric analysis with a BioPhotometer Plus instrument (Eppendorf). RNA samples were stored at $-80^{\circ} \mathrm{C}$ until further use.

\section{Reverse transcription}

$0.07 \mu \mathrm{g}$ of total RNA was reverse transcribed in a $5 \mu \mathrm{l}$ reaction volume, using SuperScript III Reverse Transcriptase (Invitrogen), a gene-specific primer $(1 \mu \mathrm{l})$, dNTP mix $(0.25 \mu \mathrm{l} ; 10 \mu \mathrm{M}$ final concentration), and $5 \times$ First-Strand Buffer $(1 \mu \mathrm{l})$. The reaction mix was incubated at $55^{\circ} \mathrm{C}$ for $60 \mathrm{~min}$ and incubation was stopped by holding at $70^{\circ} \mathrm{C}$ for $15 \mathrm{~min}$. A no-RT control reaction was run to ensure that the RNA samples were free of DNA contamination. For the quantitative RT-PCR reactions, only DNA-free RNA samples were used. Firststrand cDNAs were diluted 10-fold with Nuclease-Free Water (Promega Corp.) and stored at $-80^{\circ} \mathrm{C}$ until use. The same primers were used for the RT reaction as in our previous publication [1].

\section{Real-time PCR}

A Rotor-Gene 6000 cycler (Corbett Life Science) was used for the real-time quantitative PCR analysis. Each reaction (20 $\mu \mathrm{l}$ final volume) contained the following components: $7 \mu \mathrm{l}$ of cDNAs, $10 \mu \mathrm{l}$ of Absolute QPCR SYBR Green Mix (Thermo Fisher Scientific), $1.5 \mu \mathrm{l}$ of forward and reverse primer $(10 \mu \mathrm{M}$ each; we used the same primer pairs as described earlier [1]). The PCR cycling parameters were as follows: $95^{\circ} \mathrm{C}$ for $15 \mathrm{~min}$ (pre-incubation), and then 30 cycles of $94^{\circ} \mathrm{C}$ for $25 \mathrm{sec}$ (denaturation), $60^{\circ} \mathrm{C}$ for $25 \mathrm{sec}$ (annealing), and $72^{\circ} \mathrm{C}$ for $6 \mathrm{sec}$ (extension). The specific amplification products (with a single peak at the predicted temperature) were identified by melting-point curve analysis. An additional detection step was included in the cycle program to avoid primer dimer detection for those primer pairs that 
produce primer dimers. The reliability of the primers was verified in our earlier publication [1]. Porcine $28 \mathrm{~S}$ rRNA was used as a loading control throughout the experiment. $\mathrm{H}_{2} \mathrm{O}$ was included as a no-template control, and cDNA derived from the reverse-transcribed RNAs of non-infected cells was used as a negative mockinfected control. SYBR Green-based real-time PCR was applied in this study because of the low costs and simple protocol [51].

\section{Data analysis}

The following formula was used for calculation of the relative expression ratio $(\mathrm{R})$ :

$$
\mathrm{R}=\frac{\overline{\left(E_{\text {sample } 6 h}\right)^{C t_{\text {samplech }}}}}{\left(E_{\text {sample }}\right)^{C t_{\text {sample }}}}: \overline{\left(E_{\text {ref } 6 h}\right)^{C t_{\text {ref } 6 h}}}
$$

where $\mathrm{E}$ is the efficiency of amplification, $\mathrm{Ct}$ is the cycle threshold value, 'sample' is the examined PRV gene, and 'ref' is the $28 \mathrm{~S}$ rRNA. The Comparative Quantitation module of the Rotor-Gene 6000 Software (Version 1.7.87., Corbett Research) was used to calculate the realtime PCR efficiency for each sample. Thresholds were set by the software. The $\mathrm{R}$ values of both low and high-titre infections were maximized to the $6 \mathrm{~h} \mathrm{E}^{\mathrm{Ct}}$ values of the high-MOI experiment. To measure the net change in $\mathrm{R}$ between two consecutive time points, $R_{\Delta}$ was calculated via the following formula: $R_{\Delta}=R_{(t+1)}-R_{t}$. The rate of change was calculated as follows: $R_{a}=R_{(t+1)} / R_{t}$. Pearson's correlation was used for the analysis of the relationship between low- and high-titre infections using the following formula [52]:

$$
\mathrm{r}=\frac{\sum_{i=1}^{n}\left(X_{i}-\bar{X}\right)\left(Y_{i}-\bar{Y}\right)}{(n-1) S_{x} S_{y}}
$$

The correlation measures the linear relationship between two variables, $\mathrm{X}$ and $\mathrm{Y}$. Pearson's coefficient ( $\mathrm{r}$ ) is a number ranging from -1 to +1 that measures the degree of association between $\mathrm{X}$ and $\mathrm{Y}$. If $\mathrm{X}$ and $\mathrm{Y}$ are independent, Pearson's correlation coefficient is 0 . A positive $\mathrm{r}$ value for the correlation implies a positive association (large values of $\mathrm{X}$ tend to be associated with large values of $\mathrm{Y}$, and small values of $\mathrm{X}$ tend to be associated with small values of $\mathrm{Y}$ ). A negative value for the correlation means an inverse association (large values of $\mathrm{X}$ tend to be associated with small values of $\mathrm{Y}$, and vice versa). In the analysis of the relationship between the low and high-titre infections, $\bar{X}$ is the average $\mathrm{R}$ value of the low-titre infection at a given time point, and $\bar{Y}$ is the average $R$ value at the same time point in the hightitre infection. $S_{X}$ and $S_{Y}$ are the SEM (standard error of the mean) values and $n$ is the sample number.

\section{Additional material}

Additional file 1: The running curves of $R, R_{\Delta}$, and $R_{a}$ values.

Additional file 2: The relative expression ratio (R), the $R_{\Delta}$, and $R_{a}$ values.

Additional file 3: Comparison of $R, R_{\Delta}$ and $R_{a}$ values of low and high $\mathrm{MOI}$ infection by Pearson correlation.

\section{Acknowledgements}

This study was supported by Hungarian National Fund for Human Frontiers Science Program Young Investigator grant (No. RGY0073/2006) to Z.B.

\section{Authors' contributions}

JT carried out the standard and real-time PCR, the agarose and polyacrilamide gel electrophoresis, and the DNA sequencing, and participated in the evaluation of the primary data. DT took part by performing the reverse transcription reactions, purified PRV RNA, and propagated PK-15 cells. IT participated in performing the reverse transcription reactions. ZB coordinated the study, propagated viruses and isolated viral DNAs. All authors have read and approved the final manuscript.

\section{Competing interests}

The authors declare that they have no competing interests.

Received: 15 June 2010 Accepted: 6 December 2010

Published: 6 December 2010

\section{References}

1. Tombácz D, Tóth JS, Petrovszki P, Boldogköi Z: Whole-genome analysis of pseudorabies virus gene expression by real-time quantitative RT-PCR assay. BMC Genomics 2009, 10:491.

2. Aujeszky A: A contagious disease, not readily distinguishable from rabies, with unknown origin. Veterinarius 1902, 25:387-396.

3. Card JP, Enquist LW: Transneuronal circuit analysis with pseudorabies viruses. Curr Prot Neurosci 2001, Chapter 1(Unit 1.5):1-27.

4. Boldogköi Z, Bálint K, Awatramani GB, Balya D, Busskamp V, Viney TJ, Lagali PS, Duebel J, Pásti E, Tombácz D, Tóth JS, Takács IF, Scherf BG, Roska B: Genetically timed, activity-sensor and rainbow transsynaptic viral tools. Nat Methods 2009, 6:127-130.

5. Granstedt AE, Szpara ML, Kuhn B, Wang SS, Enquist LW: Fluorescencebased monitoring of in vivo neural activity using a circuit-tracing pseudorabies virus. PLoS One 2009, 4(9):e6923.

6. Boldogköi Z, Sík A, Dénes A, Reichart A, Toldi J, Gerendai I, Kovács KJ, Palkovits M: Novel tracing paradigms-genetically engineered herpesviruses as tools for mapping functional circuits within the CNS: present status and future prospects. Prog Neurobiol 2004, 72:417-445.

7. Prorok J, Kovács PP, Kristóf AA, Nagy N, Tombácz D, Tóth JS, Ördög B, Jost N, Virág L, Papp JG, Varró A, Tóth A, Boldogköi Z: Herpesvirusmediated delivery of a genetically encoded fluorescent $\mathrm{Ca}(2+)$ sensor to canine cardiomyocytes. J Biomed Biotechnol 2009, 2009:361795.

8. Boldogköi Z, Bratincsák A, Fodor I: Evaluation of pseudorabies virus as a gene transfer vector and an oncolytic agent for human tumor cells. AntiCancer Res 2002, 22:2153-2159.

9. Chambers J, Angulo A, Amaratunga D, Guo H, Jiang Y, Wan JS, Bittner A, Frueh $\mathrm{K}$, Jackson MR, Peterson PA, Erlander MG, Ghazal P: DNA microarrays of the complex human cytomegalovirus genome: profiling kinetic class with drug sensitivity of viral gene expression. J Virol 1999, 73:5757-5766.

10. Stingley SW, Garcia Ramirez JJ, Aguilar SA, Simmen K, Sandri-Goldin RM, Ghazal P, Wagner EK: Global analysis of herpes simplex virus type 1 transcription using an oligonucleotide-based DNA microarray. J Virol 2000, 74:9916-9927. 
11. Flori L, Rogel-Gaillard C, Cochet M, Lemonnier G, Hugot K, Chardon P, Robin S, Lefévre F: Transcriptomic analysis of the dialogue between Pseudorabies virus and porcine epithelial cells during infection. BMC Genomics 2008, 9:1-24.

12. Thompson RL, Sawtell NM: The herpes simplex virus type 1 latencyassociated transcript gene regulates the establishment of latency. J Virol 1997, 71(7):5432-5440.

13. Mador N, Goldenberg D, Cohen O, Panet A, Steiner I: Herpes simplex virus type 1 latency-associated transcripts suppress viral replication and reduce immediate-early gene mRNA levels in a neuronal cell line. $J$ Virol $1998,72: 5067-5075$.

14. Schwartz JA, Brittle EE, Reynolds AE, Enquist LW, Silverstein SJ: UL54-Null pseudorabies virus is attenuated in mice but productively infects cells in culture. J Virol 2006, 80:769-784.

15. Chen Y, Carrington-Lawrence SD, Bai P, Weller SK: Mutations in the putative zinc-binding motif of UL52 demonstrate a complex interdependence between the UL5 and UL52 subunits of the human herpes simplex virus type 1 helicase/primase complex. J Virol 2005, 79:9088-9096.

16. Klupp BG, Granzow H, Klopfleisch R, Fuchs W, Kopp M, Lenk M, Mettenleiter TC: Functional analysis of the pseudorabies virus UL51 protein. J Virol 2005, 79:3831-3840.

17. Jöns A, Gerdts V, Lange E, Kaden V, Mettenleiter TC: Attenuation of dUTPase-deficient pseudorabies virus for the natural host. Vet Microbiol 1997, 56:47-54.

18. Jöns A, Granzow H, Kuchling R, Mettenleiter TC: The UL495 gene of pseudorabies virus codes for an O-glycosylated structural protein of the viral envelope. J Virol 1996, 70:1237-1241.

19. Fuchs W, Granzow H, Klupp BG, Kopp M, Mettenleiter TC: The UL48 tegument protein of peudorabies virus is critical for intracytoplasmic assembly of infectious virions. J Virol 2002, 76:6729-6742.

20. Wu SL, Li CC, Ho TY, Hsiang CY: Mutagenesis identifies the critical regions and amino acid residues of suid herpesvirus 1 DNA-binding protein required for DNA binding and strand invasion. Virus Res 2009, 140:147-154.

21. Berthomme $H$, Monahan SJ, Parris DS, Jacquemont B, Epstein AL: Cloning, sequencing, and functional characterization of the two subunits of the pseudorabies virus DNA polymerase holoenzyme: evidence for specificity of interaction. J Virol 1995, 69:2811-2818.

22. Fuchs W, Klupp BG, Granzow H, Leege T, Mettenleiter TC: Characterization of pseudorabies virus (PrV) cleavage-encapsidation proteins and functional complementation of PrV pUL32 by the homologous protein of herpes simplex virus type 1. J Virol 2009, 83:3930-3943.

23. Fuchs W, Klupp BG, Granzow H, Mettenleiter TC: Essential function of the pseudorabies virus UL36 gene product is independent of its interaction with the UL37 protein. J Virol 2004, 78:11879-11889.

24. Braun A, Kaliman A, Boldogköi Z, Aszódi A, Fodor I: Sequence and expression analyses of the UL37 and UL38 genes of Aujeszky's disease virus. Acta Vet Hung 2000, 48:125-136.

25. Lin HW, Chang YY, Wong ML, Lin JW, Chang TJ: Functional analysis of virion host shutoff protein of pseudorabies virus. Virology 2004, 324:412-418.

26. de Wind N, Berns A, Gielkens A, Kimman T: Ribonucleotide reductasedeficient mutants of pseudorabies virus are avirulent for pigs and induce partial protective immunity. J Gen Virol 1993, 74:351-359.

27. Klupp BG, Altenschmidt J, Granzow H, Fuchs W, Mettenleiter TC: Identification and characterization of the pseudorabies virus UL43 protein. Virology 2005, 334:224-233.

28. Flynn SJ, Ryan P: The receptor-binding domain of pseudorabies virus glycoprotein $\mathrm{gC}$ is composed of multiple discrete units that are functionally redundant. J Virol 1996, 70:1355-1364

29. Dezélée S, Bras F, Vende P, Simonet B, Nguyen X, Flamand A, Masse MJ: The BamHI fragment 9 of pseudorabies virus contains genes homologous to the UL24 UL25 UL26 and UL 265 genes of herpes simplex virus type 1. Virus Res 1996, 42:27-39.

30. Babic N, Klupp BG, Makoschey B, Karger B, Flamand A, Mettenleiter TC: Glycoprotein $\mathrm{gH}$ of pseudorabies virus is essential for penetration and propagation in cell culture and in the nervous system of mice. $J$ Gen Virol 1996, 77:2277-2285
31. de Wind N, Wagenaar F, Pol J, Kimman T, Berns A: The pseudorabies virus homolog of the herpes simplex virus UL21 gene product is a capsid protein which is involved in capsid maturation. J Virol 1992, 66:7096-7103.

32. Fuchs W, Klupp BG, Granzow H, Mettenleiter TC: The UL20 gene product of pseudorabies virus functions in virus egress. J Virol 1997, 71(7):5639-5646

33. Yamada S, Imada T, Watanabe W, Honda Y, Nakajima-lijima S, Shimizu Y, Sekikawa K: Nucleotide sequence and transcriptional mapping of the major capsid protein gene of pseudorabies virus. Virology 1991, 185:56-66.

34. Klupp BG, Granzow H, Karger A, Mettenleiter TC: Identification subviral localization and functional characterization of the pseudorabies virus UL17 protein. J Virol 2005, 79:13442-16453.

35. Yamauchi Y, Wada K, Goshima F, Daikoku T, Ohtsuka K, Nishiyama Y: Herpes simplex virus type 2 UL14 gene product has heat shock protein (HSP)-like functions. J Cell Science 2002, 115:2517-2527.

36. Dijkstra JM, Visser N, Mettenleiter TC, Klupp BG: Identification and characterization of pseudorabies virus glycoprotein $\mathrm{gM}$ as a nonessential virion component. J Virol 1996, 70:5684-5688.

37. Dijkstra JM, Fuchs W, Mettenleiter TC, Klupp BG: Identification and transcriptional analysis of pseudorabies virus UL6 to UL12 genes. Arch Virol 1997, 142:17-35.

38. Dean HJ, Cheung AK: A 3' coterminal gene cluster in pseudorabies virus contains herpes simplex virus UL1 UL2 and UL3 gene homologs and a unique UL35 open reading frame. J Virol 1993, 67:5955-5961.

39. Krause PR, Croen KD, Ostrove JM, Straus SE: Structural and kinetic analyses of herpes simplex virus type I latency-associated transcripts in human trigeminal ganglia and in cell culture. J Clin Invest 1990, 86(1):235-241.

40. Cheung AK: Cloning of the latency gene and the early protein 0 gene of pseudorabies virus. J Virol 1991, 65:5260-5271.

41. Ihara S, Feldman L, Watanabe S, Ben-Porat T: Characterization of the immediate-early functions of pseudorabies virus. Virology 1983, 131:437-454.

42. Zhang G, Leader DP: The structure of the pseudorabies virus genome at the end of the inverted repeat sequences proximal to the junction with the short unique region. J Gen Virol 1990, 71:2433-2441.

43. Calton CM, Randall JA, Adkins MW, Banfield BW: The pseudorabies virus serine/threonine kinase Us3 contains mitochondrial nuclear and membrane localization signals. Virus Genes 2004, 29:131-145.

44. Rauh I, Mettenleiter TC: Pseudorabies virus glycoproteins gll and gp50 are essential for virus penetration. J Virol 1991, 65:5348-5356.

45. Brideau AD, Banfield BW, Enquist LW: The Us9 gene product of pseudorabies virus an alphaherpesvirus is a phosphorylated tailanchored type II membrane protein. J Virol 1998, 72:4560-4570.

46. Batchelor $\mathrm{AH}, \mathrm{O}^{\prime}$ Hare $\mathrm{P}$ : Regulation and cell-type-specific activity of a promoter located upstream of the latency-associated transcript of herpes simplex virus type 1. J Virol 1990, 64:3269-3279.

47. Vlcek C, Kozmik Z, Paces V, Schirm S, Schwyzer M: Pseudorabies virus immediate early gene overlaps with an oppositely oriented open reading frame - characterization of their promoter and enhancer regions. Virology 1993, 179:365-377.

48. Dittmer DP, Gonzalez CM, Vahrson W, DeWire SM, Hines-Boykin R, Damania B: Whole-genome transcription profiling of rhesus monkey rhadinovirus. J Virol 2005, 79:8637-8650.

49. Michael K, Klupp BG, Mettenleiter TC, Karger A: Composition of pseudorabies virus particles lacking tegument protein US3 UL47 or UL49 or Envelope Glycoprotein E. J Virol 2006, 80(3):1332-1339.

50. Wagner EK, Ramirez JJ, Stingley SW, Aguilar SA, Buehler L, Devi-Rao GB, Ghazal P: Practical approaches to long oligonucleotide-based DNA microarray: lessons from herpesviruses. Prog Nucleic Acid Res 2002, 71:445-491.

51. Papin J, Vahrson W, Hines-Boykin R, Dittmer DP: Real-time quantitative PCR analysis of viral transcription. Methods Mol Biol 2005, 292:449-480.

52. Campbell AM, Heyer L: Basic research with DNA microarray. In Discovering Genomics Proteomics and Bioinformatics. 2 edition. Edited by: Susan Winslow. San Francisco: CSHL Press; 2007:238-241.

doi:10.1186/1471-2180-10-311

Cite this article as: Tóth et al:: The effects of viral load on pseudorabies virus gene expression. BMC Microbiology 2010 10:311. 